Article

\title{
COVID-19 and the Non-Repayment of Agricultural Loans in West Cameroon: A major Challenge for the Small Farmer in an Individual Loan Situation
}

\author{
Yannick Tamo Fogue ${ }^{1,}{ }^{*}$, Ibrahim Manu ${ }^{2}$ \\ ${ }^{1}$ Developmental Psychologist, Rural Development Researcher, University of Yaoundé 1, Came- \\ roon \\ 2 Rural Sociologist, Rural Development Researcher, University of Dschang, Cameroon \\ *Correspondence: yannicktam@yahoo.fr
}

How to cite this paper: Tamo Fogue, Y., \& Manu, I. (2022). COVID-19 and the Non-Repayment of Agricultural Loans in West Cameroon: A major Challenge for the Small Farmer in an Individual Loan Situation. Open Journal of Agricultural Research, 2(1), 1-13. Retrieved from

https://www.scipublications.com/journal/index.php/ojar/article/view/181

Received: October 28, 2021 Accepted: January 28, 2022 Published: January 29, 2022

Copyright: (c) 2022 by the authors. Submitted for possible open access publication under the terms and conditions of the Creative Commons Attribution (CC BY) license (http://creativecommons.org/licenses /by/4.0/).

\begin{abstract}
This study raises the problem of the non-repayment of agricultural credits by producers who are members of the Community Growth Mutual $\left(\mathrm{MC}^{2}\right)$, in this period of COVID-19. It questions the economic mores in force in most member countries of the Organization for the Harmonization of Business Law in Africa (OHADA), where credit has become difficult for small rural farmers; And refers to the theory of the vicious circle of poverty, which advocates an indispensable recourse to foreign capital in the event of financial breakdown, as a means of increasing capital. Since the capital of rural producers remains insufficient and their possibility of reinvestment decreases, then becomes zero because of agricultural credit. To understand the factors of the non-repayment of these credits, data were collected from 100 agro-sylvo-pastoral producers of the Bayangam group (West-Cameroon) of both sexes, aged at least 18 years, having obtained an unpaid credit from the $\mathrm{MC}^{2}$ since 2019, and a manager of this microfinance institution. After analysis, it appears that beyond overproduction and anti-COVID-19 measures that lead to the missale or fall in prices on the market, the conditions of access to credit, the non-possession of acceptable guarantees, the misuse of the object of credit and the practice of financial cavalry by the borrower, as well as the rigidity of the procedures for prosecuting debtors significantly explain this non-repayment. It is associated with determinants such as age, level of education, marital status, type of agricultural activity of the debtor. Hence the need for flexibility of microfinance institutions vis-à-vis rural agro-sylvo-pastoral producers, who are severely affected by the economic shock of the COVID-19.
\end{abstract}

Keywords: Agro-sylvo-pastoral producer, $\mathrm{MC}^{2}$, Credit/recovery, Individual loan, COVID-19

\section{Introduction}

Microfinance is generally perceived as a set of financial and banking services for the poor. In this logic, the COBAC regulation $\mathrm{N}^{\circ} 01 / 02 / C E M A C / U M A C$ of April 13, 2002, relating to the conditions of exercise and control of the Microfinance Activity in the Economic and Monetary Community of Central Africa, defines it as authorized entities, not having the status of bank, but providing financial services to entrepreneurs with few economic resources, to help establish a small, self-managed business to eradicate poverty. This activity has experienced a strong outbreak in Cameroon, since the 90s when it diversified with Laws No. 90/053 of 19 December 1990 on freedom of Association and No. 92/006 of 14 August 1992 on Cooperative Societies and Groups of Common Initiative (GIC) [1]. It is the result of the crisis in the banking sector that has led to numerous bankruptcies, restructurings and fears among low-income populations, consequently excluded from banking services, increasing the under banking of rural areas [2]. In addition, donors have reportedly recognized that a large part of the needs of excluded populations could be met 
by credits not offered by banks, hence a legal framework giving microfinance institutions a landscape favorable to rural agro-sylvo-pastoral producers, through the granting of agricultural credits $[3,4]$. Recovery procedures, relating to the activities of recovering loans in arrears, and preventing loan defaults would also be a factor of shortness of breath for many of them [5]. Especially in this period of COVID-19 health crisis that has made it difficult to trade with the countries of the sub-region, constitutes a major obstacle to the development of the Social Economy [6].

\subsection{Context and problems of the study}

The economic impact of COVID-19 would have cost the African continent more than one percentage point of GDP (from 1.8\% to 3.2\%) [7]. In Cameroon, there is a free fall in the exchange of all raw materials (cocoa, cotton, minerals, etc.), and even products of direct consumption, due to the limitation of the movement of people (in places of commerce and leisure areas, food stores and pharmacies, parks and means of public transport, workplaces and areas of residence) [8]. This illustrates the drastic decline in socio-economic activities. The informal sector, which accounts for nearly $50 \%$ of GDP, is increasingly sinking into precariousness, especially in rural areas, which are essentially agro-sylvo-pastoral. With an immediate and direct consequence not only on tax revenues and for the public treasury, but mainly on the producer who is the most vulnerable link in the economic chain [9]. However, before the beginning of the crisis, Cameroon had already recorded an estimated growth rate of $4.1 \%$ in 2019 [10].

However, even if the legal conditions for granting credit are relatively flexible and favorable in microfinance, the procedures for debt collection do not differ from those of banks and insurance companies. Thus, the client, just like the institution could take the status of debtor or creditor, with a third party like the tax administration to recover the tax claims, either amicably, judicially, or by forced means such as seizure [11, 12]. Theoretically, this is in line with the economic mores in force in most member countries of the Organization for the Harmonization of Business Law in Africa (OHADA), where credit has become difficult and rural producers are increasingly reluctant, but losing trust between creditors and debtors would be the end of credit, which is nevertheless the foundation of an emerging and sustainable rural economy [13]. Thus, to generate good habits and a culture of credit repayment, the applicable text is the uniform act on the organization of simplified recovery procedures and enforcement procedures of 10 April 1998, provides for the order for payment and to issue or return, and tends to facilitate the recovery of debts and to obtain the delivery or restitution of specific movable property [14]. On a practical level, within the Economic and Monetary Community of Central Africa (CEMAC), there are three (03) categories of Microfinance Institutions, whose application of simplified recovery procedures promotes the security of creditors. The first category collects members' savings and grants them credits, the second collects savings and grants loans to third parties so operations are open to the public, and the third, more specialized in investment, transfers credit to third parties without prior deposit [15]. In doing so, any creditor whose right or credibility is not disputed by the debtor, can quickly and inexpensively obtain an enforceable title allowing him to practice an attachment attribution or convert a seizure into seizure attribution or even seizure-sale [16]. Similarly, they allow EMFs to easily obtain the delivery/return of a specific movable property at the value of the credit contracted.

The Community Growth Mutual (MC2/MUFFA) is an approach aimed at enabling populations, especially peasants, to take charge of themselves and create wealth through adapted financial instruments, in order to improve their living conditions in a sustainable 
way. Having been designed with the support of Afriland First Bank and the non-governmental organization ADAF (Appropriate Development for Africa Foundation), it has been developing in different communities since 1992, with the help of the populations and various partners. It is based on the principle that: Victory over Poverty (VP) is possible if the Means (M) and Competences (C) of the Community (C) are put together (VP $=\mathrm{M} \times \mathrm{C} \times \mathrm{C}=$ $\mathrm{MC}^{2}$ ) [17]. Its objective is economic/financial viability, as well as actions aimed at the poor and micro/small activities, the provision of a development instrument that would promote the development of rural communities, with the aim of combating poverty, combating unemployment and developing income-generating activities. Its economic development process consists of 5 main phases, namely: raising awareness among elites and rural populations about its foundations; the mobilization of savings and deposits, sources of investment in any economy; the allocation of this savings to the financing of agro-pastoral economic activities, which create wealth; the implementation of community economic projects likely to exploit local resources in order to generate the capital gains necessary for the financing of development; the development of community social projects thanks to the resources generated [18]. But with the COVID-19 pandemic, interviews with 266 people in 12 West African countries reveal many negative economic and financial repercussions, particularly severe for rural producers who bear the greatest burden of caring for their families by selling their crops [19].

\subsection{Problem of the study}

Insufficient capital is increasingly leading to low investment among agro-silvo-pastoral producers in rural areas. It reduces their productivity and keeps their incomes relatively low, thus hindering their socio-economic development. In doing so, the capital of these small farmers remains insufficient and their possibility of reinvestment decreases and then becomes zero. This is the vicious circle of poverty [20], the breaking of which imperatively requires recourse to foreign capital that will allow an increase in capital, productivity, consumption demand and subsequently, income. Thus, the provision of credit by microfinance institutions helps to bridge the gap between the investment and savings needs available to rural producers [21]. These external resources through prior credit create economic activities allowing them to generate a surplus necessary for the repayment of loans and the constitution of savings. However, it is possible to mobilize prior savings in rural areas, more for reasons of security and liquidity than for reasons of remuneration. But under these conditions, farmers' motivation to repay credit from their own savings is much stronger than if the funds come from outside [22]. However, this credit cycle is difficult to access for most rural producers [23].

This requires a sociological investigation both on the procedures for granting credit and debt collection, as well as on the socio-economic handicaps potential to the credibility and development of small rural farmers. Indeed, following certain anti-COVID-19 measures such as the closure of borders, the prices of agricultural inputs have increased, the producers' market has been restricted/limited (no export), the prices of agricultural products have fallen due to abundance and the obligation to sell locally. Many producers have been forced, failing to let them rot in the fields, to sell off/liquidate their crops at a loss and remain over-indebted. In the case of tomatoes, the average production, being estimated at 889,800 tons per year, it now floods the markets, where the prices of crates have drastically fallen to 1,000 or 2,000 CFA francs, almost ten times lower than the prices of the precovidic period [24]. This constitutes a major obstacle to the development of the Social Economy of these small farmers; because for $93.7 \%$ of them, the barrier measures taken by the government (closure of markets, limitation of travel, etc.) have caused their incomes to plummet, which depend mainly on agriculture and livestock [25]. 
In addition, the scientific literature mainly questions the obstacles to the repayment capacities of agricultural credits, assuming that borrowers are part of a group [26, 27, 28, 16]. On the other hand, the majority of borrowers do so on an individual basis and therefore provide personal and not group security as security. In this case, it is easily observable that during the collection processes, microfinance institutions stick only to the personal property of the debtor and cannot turn to a group to which the debtor belongs. However, we notice limits in significantly more numerous producers in rural areas where the group is what is called "tontine", and who, not having a legal-legal status, cannot, except statutory adjustment of the Community Growth Mutual $\left(\mathrm{MC}^{2}\right)$, endorse one of its members during the loan. So far, the system of credit/recovery in individual loans is not yet heuristically questioned as a socio-economic factor hindering the credibility and development of rural producers in the member countries of the Organization for the Harmonization of Business Law in Africa (OHADA). This work therefore studies the case of individuals who are not members of groups, who have decided as farmers to join the $\mathrm{MC}^{2}$, where they have applied in this period of COVID-19, for an individual credit to boost their agro-sylvopastoral activities.

\subsection{Research hypothesis}

This research predicts that: In times of COVID-19, the non-repayment of agricultural credits is due to factors such as: the conditions of access to credits, the non-possession of acceptable guarantees, the misappropriation of the object of credit by the borrower, the practice of financial cavalry and the rigidity of the procedures for prosecuting debtors at the Community Growth Mutual $\left(\mathrm{MC}^{2}\right)$. It is associated with determinants such as age, level of education, marital status, type of agro-sylvo-pastoral activity of the debtor.

\section{Method}

\subsection{Participants}

100 agro-sylvo-pastoral producers from the Bayangam group (West Cameroon) participated as units of analysis in this research. Having obtained a credit from the Community Growth Mutual $\left(\mathrm{MC}^{2}\right)$ and being recognized as insolvent since 2019, they are of both sexes, aged at least 18 years. A manager of this microfinance institution also participated as a reporting unit.

\subsection{Material and procedure}

First of all, secondary data were collected from the archives and documents of the Community Growth Mutual ( $\left.\mathrm{MC}^{2}\right)$ in Bayangam (West Cameroon), which provided information on the normative framework for granting credit and recovery, and then made it possible to identify the farmers who took out loans there. Then, using an interview guide, we interviewed a reporting unit who provided additional information on the organization and operation of this microfinance institution, its partnership dynamics with the agrosylvo-pastoral producers of the group, and facilitated contact with their clients willing to answer the survey questionnaire. Thus, a list of 110 insolvent farmers was made available with numbers that made it possible to contact them and invite them within the structure for an investigation. 100 who had actually honored the appointment, answered a questionnaire divided into 5 headings including: general information about the respondent; knowledge of the $\mathrm{MC}^{2}$ and its normative framework; the purpose and amount of the credit contracted; the inventory of the reimbursement and the difficulties ad relating thereto; solicitations to increase its repayment capacity. 


\subsection{Data processing}

A thematic content analysis is made on the data collected by interview, those collected by questionnaire are analyzed on the statistical software SPSS 21 (Statistical package for social sciences).

\section{Result}

This research has made it possible to identify that the socio-economic factors hindering the credibility of agro-sylvo-pastoral producers, with the Community Growth Mutual $\left(\mathrm{MC}^{2}\right)$ of the Bayangam community, are linked to age groups, levels of education, marital status and types of activity carried out by the debtor, closely associated with the implications of credit/recovery in individual loans, characterized by legal-legal determinants with relative repercussions on their repayment capacities. Indeed, it appears that the conditions of access to credits are binding for $63 \%$ of the participants, unlike $37 \%$ who find them relatively flexible for an average producer. One reporting unit of the structure states:

"To grant credit to our members, the structures of the $M C^{2}$ model respect a number of conditions related to the age of the applicant, his financial situation, the volume of outstanding claims, his level of coverage of the commitments by the available resources, the target, the duration, the object, the amount of the credit, the interest rate and the guarantees. The HIPC funds allocated to microfinance institutions provide a first solution to the problems of financing agro-pastoral activities by relaxing the conditions attached to the young farmer who requests credit. To benefit from financing at MC Bayangam, under the HIPC Fund, you must be a farmer, because the purpose of THE HIPC funds is to support the farmer in the search for financing, but it is first necessary that the one who seeks the financing is followed by an Agricultural Extension Officer, in order to strengthen his capacity to manage the credit that will be made available to him to finance his activities. Through this monitoring, $M C^{2}$ would like to ensure the proper use of the funds made available to the farmer, the possibilities of return on investment, and the guarantees of recovery. Credit is granted to small farmers who have real security, and personal guarantees at market value representing at least $100 \%$ of the amount of credit requested, to prevent difficulties at the time of repayment".

But it is noted that a proportion slightly below the average of these small producers $(49 \%)$ have acceptable personal guarantees, but $51 \%$ of them have nothing to prevent difficulties when repaying their credits. Thus, they are endorsed by third parties, officials or treasurer of the "tontines", which according to their affinities, constitute in their place pledges of cash, pledges of term deposits or, having savings accounts and other regular income, or movable/immovable property at loan value, which agree between the parties to hand them over to the creditor to guarantee the payment of their debt, of which several of them are unfortunately not able to do so. Microfinance is however assigned to the mission of offering local financial services to the poor, composed in particular of small independent farmers or organized in groups, and should participate through savings and agricultural credit, in the socio-economic development of low-income rural producers, ineligible for the traditional banking sector for lack of guarantees having credit value, and therefore, in difficulty of access to financial resources. However, $63 \%$ of these $\mathrm{MC}^{2}$ debtors do not practice financial cavalry.

The majority of them find that their main bottleneck in this time of COVID-19 is in the debt collection process, which in this microfinance institution is characterized by a debtor prosecution procedure, which smallest agro-sylvo-pastoral producers (94\%) describe as very restrictive because of the interest rate. However, an $\mathrm{MC}^{2}$ official reveals that "the interest rate applied in the structures of the $\mathrm{MC}^{2}$ model is between $12 \%$ and $14 \%$ per year, set by the board of directors after consultation with the support structures, which applies defined by tranches of the amount, in order to encourage the poor to invest". Nevertheless, believing these 
procedures to be rather flexible, $6 \%$ of participants believe that their insolvency problem lies elsewhere. It is always noted that the majority $(60 \%)$, they invest their credits in the activities for which they are actually intended, but some (40\%) because of the risks anticipated at the beginning of the projects for which the loan has been granted, divert the object of the credit, claiming to maximize the return on investment and increase the possibilities of repayment.

Table 1. Age-related characteristics and legal determinants of the difficult repayment of agricultural loans by debtors of the $\mathrm{MC}^{2}$ Bayangam.

\begin{tabular}{|c|c|c|c|c|c|c|c|c|c|c|}
\hline \multirow{3}{*}{$\begin{array}{l}\text { Juridical determi- } \\
\text { nants }\end{array}$} & \multicolumn{10}{|c|}{ Age groups } \\
\hline & \multicolumn{2}{|c|}{ [18-45] } & \multicolumn{2}{|c|}{$[46-55]$} & \multicolumn{2}{|c|}{$[56-60]$} & \multicolumn{2}{|c|}{ Plus de 60} & \multicolumn{2}{|c|}{ Total } \\
\hline & $\mathrm{n}=15$ & $\%$ & $\mathrm{n}=35$ & $\%$ & $\mathrm{n}=43$ & $\%$ & $\mathrm{n}=7$ & $\%$ & $\mathrm{~N}=100$ & $\% \mathrm{~T}$ \\
\hline \multicolumn{11}{|c|}{ Conditions of access to credits } \\
\hline Binding & 11 & 73.33 & 23 & 65.71 & 25 & 58.14 & 4 & 57.14 & 63 & 63.00 \\
\hline Non-binding & 4 & 26.67 & 12 & 34.29 & 18 & 41.86 & 3 & 42.86 & 37 & 37.00 \\
\hline \multicolumn{11}{|c|}{ Acceptable warranty } \\
\hline Have & 5 & 33.33 & 15 & 42.86 & 24 & 55.81 & 5 & 71.43 & 49 & 49.00 \\
\hline Do not have & 10 & 66.67 & 20 & 57.14 & 19 & 44.19 & 2 & 28.57 & 51 & 51.00 \\
\hline \multicolumn{11}{|c|}{ Financial Cavalry } \\
\hline Practice & 6 & 40.00 & 14 & 40.00 & 15 & 34.88 & 2 & 28.57 & 37 & 37.00 \\
\hline Do not practice & 9 & 60.00 & 21 & 60.00 & 28 & 65.12 & 5 & 71.43 & 63 & 63.00 \\
\hline \multicolumn{11}{|c|}{ Proceedings for the prosecution of debtors at the $\mathrm{MC}^{2}$} \\
\hline Binding & 13 & 86.67 & 33 & 94.29 & 41 & 95.35 & 7 & 100.00 & 94 & 94.00 \\
\hline Non-binding & 2 & 13.33 & 2 & 05.71 & 2 & 04.65 & 0 & 0.00 & 6 & 06.00 \\
\hline \multicolumn{11}{|c|}{ Misappropriation of the object of credit } \\
\hline Divert & 7 & 46.67 & 20 & 57.14 & 11 & 25.58 & 2 & 28.57 & 40 & 40.00 \\
\hline Do not divert & 8 & 53.33 & 15 & 42.86 & 32 & 74.42 & 5 & 71.43 & 60 & 60.00 \\
\hline
\end{tabular}

Note that: $\mathrm{n}=$ number of participants for each age group (in higher mage); $\%=$ marginal frequencies column of legal determinants; $\mathrm{N}=$ total sample size; $\% \mathrm{~T}=$ Total frequencies out of 100

Among debtors of the $\mathrm{MC}^{2}$ Bayangam who are agro-sylvo-pastoral producers, 15 are aged 18 to 45 years, 35 from 46 to 55 years, 43 from 56 to 60 years and 7 over 60 years. They find its conditions of access to credit restrictive, with a high proportion of the first two age groups (73.33\% and 65.71\%) and slightly above the average for the last two (58.14\% and $57.14 \%$ ). As for acceptable guarantees, respectively $66.67 \%$ and $57.14 \%$ of the first two age groups do not have them, but for the last two, respectively $55.81 \%$ and $71.43 \%$ have them. This indicates that the younger the rural producer, and therefore relatively less experienced, without cash pledges, without savings accounts or collateral for term deposits, without regular income, and without own movable/immovable property at the value of the loan, the more he is unable to provide real security or personal guarantees equivalent to the amount he is requesting. And this is the main handicap to agro-sylvo-pastoral entrepreneurship of young people in rural areas. It should be noted that the older rural producers are, the less financial cavalry they practice (respectively $40.00 \% ; 40.00 ; 34.88 ; 28.57$ ), but overall in all age groups, less than half do. However, all producers over the age of 60 find the procedures for pursuing $\mathrm{MC}^{2}$ very restrictive, and it is nevertheless for very large proportions of the first three age groups (respectively 86.67\%; 94.29\%; 95.35). However, many of them do not divert the object of their credit (53.33 of the first age group), especially the oldest (respectively $74.42 \%$ and $71.43 \%$ of the last two age groups), nevertheless $57.14 \%$ of those aged 46 to 55 do so. 
Table 2. Characteristics related to the level of education and legal determinants of the difficult repayment of agricultural credits by debtors of the $\mathrm{MC}^{2}$ Bayangam

\begin{tabular}{|c|c|c|c|c|c|c|c|c|c|c|}
\hline \multirow{3}{*}{$\begin{array}{l}\text { Juridical deter- } \\
\text { minants }\end{array}$} & \multicolumn{10}{|c|}{ Levels of school education } \\
\hline & \multicolumn{2}{|c|}{ Not been in school } & \multicolumn{2}{|c|}{ Primary school } & \multicolumn{2}{|c|}{ Secondary school } & \multicolumn{2}{|c|}{ University } & \multicolumn{2}{|c|}{ Total } \\
\hline & $\mathrm{n}=13$ & $\%$ & $\mathrm{n}=49$ & $\%$ & $\mathrm{n}=36$ & $\%$ & $\mathrm{n}=2$ & $\%$ & $\mathrm{n}=100$ & $\%$ \\
\hline \multicolumn{11}{|c|}{ Conditions of access to credits } \\
\hline Binding & 8 & 61.54 & 26 & 53.06 & 27 & 75.00 & 2 & 100.00 & 63 & 63.00 \\
\hline Non-binding & 5 & 38.46 & 23 & 46.94 & 9 & 25.00 & 0 & 00.00 & 37 & 37.00 \\
\hline \multicolumn{11}{|c|}{ Acceptable warranty } \\
\hline Have & 2 & 15.38 & 28 & 57.14 & 18 & 50.00 & 1 & 50.00 & 49 & 49.00 \\
\hline Do not have & 11 & 84.62 & 21 & 42.86 & 18 & 50.00 & 1 & 50.00 & 51 & 51.00 \\
\hline \multicolumn{11}{|c|}{ Financial Cavalry } \\
\hline Practice & 4 & 30.77 & 28 & 57.14 & 5 & 13.89 & 0 & 00.00 & 37 & 37.00 \\
\hline Do not practice & 9 & 69.23 & 21 & 42.86 & 31 & 86.11 & 2 & 100.00 & 63 & 63.00 \\
\hline \multicolumn{11}{|c|}{ Proceedings for the prosecution of debtors at the $\mathrm{MC}^{2}$} \\
\hline Binding & 13 & 100.00 & 45 & 91.84 & 34 & 94.44 & 2 & 100.00 & 94 & 94.00 \\
\hline Non-binding & 0 & 00.00 & 4 & 08.16 & 2 & 05.56 & 0 & 00.00 & 6 & 06.00 \\
\hline \multicolumn{11}{|c|}{ Misappropriation of the object of credit } \\
\hline Divert & 8 & 61.54 & 19 & 38.78 & 13 & 36.11 & 0 & 00.00 & 40 & 40.00 \\
\hline Do not divert & 5 & 38.46 & 30 & 61.22 & 23 & 63.89 & 2 & 100.00 & 60 & 60.00 \\
\hline
\end{tabular}

Note that: $\mathrm{n}=$ number of participants for each level of study (in higher mage); $\%=$ marginal frequencies column of legal determinants; $\mathrm{N}=$ total sample size; $\% \mathrm{~T}=$ Total frequencies out of 100

Several agro-sylvo-pastoral producers of the Bayangam group, debtors of the $\mathrm{MC}^{2}$, have the minimum of cognitive tools necessary, allowing them to read, write and count. Indeed, an analysis of their levels of education shows that 2 of them have made universality and 36 have passed the secondary school. No offense, 49 participants who have only done primary school, do not have for the most part the Certificate of Primary Studies. It is also noted that 13 of them have never been to school. They find in large proportion, whether out-of-school producers or university-educated, that the conditions of access to credit are restrictive in this microfinance institution (respectively $61.54 \% ; 53.06 \% ; 75.00 \%$; $100 \%)$. However, the vast majority of out-of-school rural producers $(84.62 \%)$ do not have an acceptable personal guarantee. In addition, apart from those who have completed primary school, of which $56.14 \%$ have it, the higher the level barely $50 \%$ have real security equivalent to their credits, and the less they practice financial cavalry (primary $=57.14 \%$; secondary $=13.89 \% ; 0 \%$ of academics). It should be noted that only $30.77 \%$ of the out-ofschool do it, but all, as well as those who have done university find the procedures for prosecuting debtors binding on the $\mathrm{MC}^{2}$, it is the same for $91.84 \%$ of producers who have done only primary school, as well as for $94.44 \%$ of those who have stopped at secondary school. However, the higher their level, the less they divert the object of their credit (out of school $=61.54 \%$; primary $=38.78 \%$; secondary $=36.11 \% ; 0 \%$ of academics). 
Table 3. Characteristics related to marital status and legal determinants of the difficult repayment of agricultural credits by debtors of the $\mathrm{MC}^{2}$ Bayangam

\begin{tabular}{|c|c|c|c|c|c|c|c|c|c|c|}
\hline \multirow{3}{*}{$\begin{array}{l}\text { Juridical determi- } \\
\text { nants }\end{array}$} & \multicolumn{10}{|c|}{ Matrimonial status } \\
\hline & \multicolumn{2}{|c|}{ Bachelor } & \multicolumn{2}{|c|}{ Married } & \multicolumn{2}{|c|}{ Widower } & \multicolumn{2}{|c|}{ Divorced } & \multicolumn{2}{|c|}{ Total } \\
\hline & $\mathrm{n}=5$ & $\%$ & $\mathrm{n}=73$ & $\%$ & $\mathrm{n}=18$ & $\%$ & $\mathrm{n}=4$ & $\%$ & $\mathrm{n}=100$ & $\%$ \\
\hline \multicolumn{11}{|c|}{ Conditions of access to credits } \\
\hline Binding & 4 & 80.00 & 45 & 61.64 & 10 & 55.56 & 4 & 100.00 & 63 & 63.00 \\
\hline Non-binding & 1 & 20.00 & 28 & 38.36 & 8 & 44.44 & 0 & 00.00 & 37 & 37.00 \\
\hline \multicolumn{11}{|c|}{ Acceptable warranty } \\
\hline Have & 0 & 00.00 & 44 & 60.27 & 5 & 27.78 & 0 & 0.00 & 49 & 49.00 \\
\hline Do not practice & 5 & 100.00 & 29 & 39.73 & 13 & 72.22 & 4 & 100.00 & 51 & 51.00 \\
\hline \multicolumn{11}{|c|}{ Financial Cavalry } \\
\hline Practice & 3 & 60.00 & 25 & 34.25 & 6 & 33.33 & 3 & 75.00 & 37 & 37.00 \\
\hline Do not practice & 2 & 40.00 & 48 & 65.75 & 12 & 66.67 & 1 & 25.00 & 63 & 63.00 \\
\hline \multicolumn{11}{|c|}{ Proceedings for the prosecution of debtors at the $\mathrm{MC}^{2}$} \\
\hline Binding & 5 & 100.00 & 69 & 94.52 & 16 & 88.89 & 4 & 100.00 & 94 & 94.00 \\
\hline Non-binding & 0 & 00.00 & 4 & 05.48 & 2 & 11.11 & 0 & 00.00 & 6 & 06.00 \\
\hline \multicolumn{11}{|c|}{ Misappropriation of the object of credit } \\
\hline Divert & 3 & 60.00 & 26 & 35.62 & 7 & 38.89 & 4 & 100.00 & 40 & 40.00 \\
\hline Do not divert & 2 & 40.00 & 47 & 64.38 & 11 & 61.11 & 0 & 00.00 & 60 & 60.00 \\
\hline
\end{tabular}

Note that: $\mathrm{n}=$ number of participants for each marital status (in higher mage); $\%=$ marginal frequencies column of legal determinants; $\mathrm{N}=$ total sample size; $\% \mathrm{~T}=$ Total frequencies out of 100

Among the agro-sylvo-pastoral producers of the Bayangam group who have contracted the credit with the Community Growth Mutual $\left(\mathrm{MC}^{2}\right)$ and who participated in this study, 5 are single, 73 married, 18 widowed and 4 divorced, of which respectively $80 \%$, $61.64 \%, 55.56 \%$ and $100 \%$ find restrictive the conditions of access to agricultural credit. Although none of the single and divorced have an acceptable guarantee, they practice in relatively above average proportions (60\% and $75 \%$ respectively), financial cavalry and all think that the procedures for prosecuting debtors by this microfinance institution are binding. Nevertheless, $60.27 \%$ of the bride and groom and $27.78 \%$ of the widowers with the security to the extent of their loans, but very few of them (respectively $34.25 \%$ and $33.33 \%$ ) engage in this practice which would be an obstacle to their possibility of repayment, although respectively $94.52 \%$ and $88.89 \%$ find that the $\mathrm{MC}^{2}$ should relax its procedures for collecting debts from its debtors, who still find them binding. It should also be noted that respectively $60 \%, 35.62 \%$ and $38.89 \%$ of single, married or widowed rural producers, as well as all divorced people who are in a situation of insolvency with regard to this microfinance institution, have diverted the object of their credits. 
Table 4. Characteristics related to the type of agro-sylvo-pastoral activities and legal determinants of the difficult repayment of agricultural credits by the debtors of the $\mathrm{MC}^{2}$ Bayangam

\begin{tabular}{|c|c|c|c|c|c|c|c|c|c|c|}
\hline \multirow{3}{*}{$\begin{array}{l}\text { Juridical determi- } \\
\text { nants }\end{array}$} & \multicolumn{10}{|c|}{ Type of agro-sylvo-pastoral activity } \\
\hline & \multicolumn{2}{|c|}{ Handicraft } & \multicolumn{2}{|c|}{ Breeding } & \multicolumn{2}{|c|}{ Agriculture } & \multicolumn{2}{|c|}{ Mixed } & \multicolumn{2}{|c|}{ Total } \\
\hline & $\mathrm{n}=6$ & $\%$ & $\mathrm{n}=9$ & $\%$ & $\mathrm{n}=21$ & $\%$ & $\mathrm{n}=64$ & $\%$ & $\mathrm{n}=100$ & $\%$ \\
\hline \multicolumn{11}{|c|}{ Conditions of access to credits } \\
\hline Binding & 5 & 83.33 & 5 & 55.56 & 15 & 71.43 & 38 & 59.38 & 63 & 63.00 \\
\hline Non-binding & 1 & 16.67 & 4 & 44.44 & 6 & 28.57 & 26 & 40.62 & 37 & 37.00 \\
\hline \multicolumn{11}{|c|}{ Acceptable warranty } \\
\hline Have & 2 & 33.33 & 4 & 44.44 & 3 & 14.29 & 40 & 62.50 & 49 & 49.00 \\
\hline Do not practice & 4 & 66.67 & 5 & 55.56 & 18 & 85.71 & 24 & 37.50 & 51 & 51.00 \\
\hline \multicolumn{11}{|c|}{ Financial Cavalry } \\
\hline Practice & 3 & 50.00 & 2 & 22.22 & 5 & 23.81 & 27 & 42.19 & 37 & 37.00 \\
\hline Do not practice & 3 & 50.00 & 7 & 77.78 & 16 & 76.19 & 37 & 57.81 & 63 & 63.00 \\
\hline \multicolumn{11}{|c|}{ Proceedings for the prosecution of debtors at the $\mathrm{MC}^{2}$} \\
\hline Binding & 6 & 100.00 & 9 & 100.00 & 18 & 85.71 & 61 & 95.31 & 94 & 94.00 \\
\hline Non-binding & 0 & 00.00 & 0 & 00.00 & 3 & 14.29 & 3 & 04.69 & 6 & 06.00 \\
\hline \multicolumn{11}{|c|}{ Misappropriation of the object of credit } \\
\hline Divert & 0 & 00.00 & 0 & 00.00 & 7 & 33.33 & 33 & 51.00 & 40 & 40.00 \\
\hline Do not divert & 6 & 100.00 & 9 & 100.00 & 14 & 66.67 & 31 & 48.44 & 60 & 60.00 \\
\hline
\end{tabular}

Note that: $\mathrm{n}=$ number of participants for each type of agro-sylvo-pastoral activity (in higher mage); \% $=$ marginal frequencies column of legal determinants; $\mathrm{N}=$ total sample size; $\% \mathrm{~T}=\mathrm{Total}$ frequencies out of 100; Mixed means at least two of the three types of activity at a time.

The rural producers of the Bayangam group invest their credits in various agro-syvopastoral speculations. Among those who have obtained loans from the Community Growth Mutual $\left(\mathrm{MC}^{2}\right), 6$ practice only crafts, including basketry, basket making, raffia mats for roofing, sleeping or drying, furniture (rattan chairs, bamboo beds ...), the manufacture by wood carving of musical instruments (tam-tam, drums), kitchen utensils (mortar, pestle, spatula), statuettes and masks; 9 are only small and large livestock farmers, including pigs, goats, sheep, beef and poultry; 21 are only involved in agriculture, in particular cash crops (coffee, banana (plantain and sweet)), tubers (macabo, yam, cassava, sweet potato, potato), cereals (maize, groundnut, cucumber, beans), market gardeners (tomatoes, vegetables, cabbage, okra, chilli) and orchards (avocado, mangoes, cola nuts, etc.); 64 are simultaneously involved in at least two of these speculations. However, $83.33 \%$ of craftsmen, $55.56 \%$ of breeders, $71.43 \%$ of farmers and $59.38 \%$ of producers who make a mixed peasantry, find that the conditions of access to credits set by the $\mathrm{MC}^{2}$ are restrictive, but a large proportion of the first three, respectively $66.67 \%, 55.56 \%$ and $85.71 \%$ do not have an acceptable guarantee or personal security, against $62.5 \%$ of mixed producers who have it. But apart from the $50 \%$ of craftsmen who practice financial cavalry, a small proportion of the other three (respectively $22.22 \%, 23.81 \%$ and $42.19 \%$ ) do so. Thus, all craftsmen and breeders, although finding the procedure of prosecution of debtors by this microfince binding, do not divert the object of their credits. However, of the $85.71 \%$ of farmers and $95.31 \%$ of mixed producers with the same apprehension of this procedure, respectively $33.33 \%$ and $51.00 \%$ divert the purpose of their credits.

\section{Discussion.}


This study aimed to analyze the socio-economic factors hindering the credibility of rural producers of the Bayangam group with the Community Growth Mutual ( $\left.\mathrm{MC}^{2}\right)$, particularly the case of individuals who are not members of peasant groups or organizations, who have decided as agro-sylvo-pastoral farmers to apply for a credit to boost their activities. Especially those who since the beginning of the health crisis to COVID-19, cannot repay their credits. It follows that the system of credit/recovery in individual loan of this financial institution at the service of the rural world, is characterized by legal-legal determinants with repercussions relatively inhibiting the repayment capacities of the credits they contract. These are the factors related to the conditions of access to credit that they find relatively restrictive $(63 \%)$, the non-availability of real security to prevent repayment difficulties (only $49 \%$ have them), the practice of financial cavalry for some of them (37\%), the procedures for prosecuting debtors, which for the most part (94\%) constitute a main bottleneck. Others even divert the object of their credit (40\%), because of the potential risks relatively anticipated at the beginning of the projects for which the loan was granted. This further affects their possibilities of return on investment and their ability to repay. These determinants are closely associated with the age, level of education, marital status and type of agro-sylvo-pastoral activity of the debtor. In this logic, research previously focused on individual borrowers of bank credit, had as independent variables relating to their level of education, the loan for housing, the area of cultivated land, the duration of membership, access to other sources of credit and other personal characteristics of the subject $[27,29,16]$. They noted that education significantly reduces the likelihood of default by the debtor. In addition, they find a positive impact of access to another source of credit on repayment performance and find that the home loan is a liability and significantly increases repayment problems.

The idea of creating the $\mathrm{MC}^{2}$ agricultural cooperative in the Bayangam group (OustCameroon), was intended to allow rural farmers to have access to financial resources in order to boost their agricultural production and improve their socio-economic development. Paradoxically, it can be seen that several rural producers who individually apply for agricultural microcredits there encounter a lot of repayment difficulties. The literature reveals that this may be linked to an information asymmetry that influences the functioning of liberalized financial markets [30], the absence of a coherent consultation framework, the lack of mastery of the regulatory framework by farmers, the inadequacy of the monitoring and internal control system, as well as the lack of professionalism of some stakeholders in the sector $[31,25]$. We also note the risk related to the types of activities financed and the characteristics of debtors [27], shocks or unexpected events affecting the borrower, not to mention the inefficiency of the functioning of creditor institutions [26]. In this logic, Zeller [32] questions the effect of slowness in procedures, and also shows that when credit is granted late, its impact on repayment rates is negative. In addition, the non-repayment of credits received by farmers is not always voluntary, because in most cases the money they receive is used to finance fertilizers and other inputs, but the harvest, under the combined effect of the increase in supply and the need to have income, these farmers are forced to sell their produce at prices that fail to cover all of their costs, including the repayment of their credits $[33,34]$. However, OHADA aims to have the regulations on the recovery of debts and their implementation recognized through the mechanism provided for by the uniform act, to prepare an effective recovery upstream but also to control the stakes of amicable recovery, judicial or by recourse to arbitration [14, 16]. The concern is to promote the socio-economic development of those excluded from banking services, who are mostly peasants, rural producers underbanked, and who should remain limitless both theoretically and practically in the microfince establishments in rural areas. 
In analyzing a small agricultural credit promotion (PPPCR) project in Burkina Faso, Paxton, Graham and Thraen [35] used an econometric model to indicate that the socioeconomic homogeneity of the group (in terms of ethnicity, occupation, income, etc.), and the domino effect significantly increase repayment problems. Thus, the higher the degree of homogeneity, the more the trend of the domino effect of the members of the group is preponderant and the higher the problems of reimbursement will be. Using 1629 observations from Grameen Bank borrowers, the Bangladesh Rural Advancement Committee and the Bangladesh Rural Development Broad, Godquin [26] found that the effect of social ties between group members on repayment is negative, as the long time spent in the group makes its members unable to apply sanctions on defaulting members among them. It also demonstrated that the homogeneity of the group, the rationing of credit which is a measure of the dynamic incentive and the size of the group do not affect the repayment performance. It also shows that the difficulty of repayment is related to the small loan, but the large loan promotes the success of the agricultural project over time and gives a positive effect on repayment. However, the size of the loan can have a detrimental effect, resulting from the increased risk faced by the project of an agro-silvo-pastoral producer because of its size. We note, however, that living in urban areas is positively correlated with good reimbursement performance for producers who, carrying out other activities in the city, temporarily migrate to rural areas to practice peasant activities [36]. These economic activities allow them to generate a surplus necessary for the repayment of loans and the constitution of savings. On the other hand, the results of this study show that in individual lending situations, farmers in rural areas express higher repayment problems. This could be due to the high risk associated with the type of rural agro-sylvo-pastoral activities in which Bayangam producers invest, forcing those debtors of the $\mathrm{MC}^{2}$ to default on their commitments during the harvest seasons, due to difficulties in the evacuation of products and falling market prices. In addition, it should be noted that producers located in sectors where many others have already failed to meet their commitments tend to show poor repayment performance. Hence the need to practice a mixed peasantry in order to compensate for the production deficits of certain speculations.

\section{Conclusion}

In short, it should be noted that all loans granted by the $\mathrm{MC}^{2}$ must be covered by the required guarantees which are of three kinds, including the applicant and his project, in particular his morality, his ability (or experience) to manage his project, his financial surface (his personal report) and the profitability of the project; financial guarantees, consisting of cash pledges, pledges of term deposits and savings accounts, and other regular income, etc., the contract by which movable property is handed over to the creditor or to a third party agreed between the parties to guarantee payment of the debt; personal guarantees, mainly simple deposit, joint and several guarantee and death disability insurance. Here, the guarantor undertakes to the creditor (mutual), who agrees to repay the credit of the debtor (beneficiary) if the latter does not respect his commitments $[18,17]$. In doing so, this microfinance institution could develop a land strategy of guarantees, in partnership with the district municipalities, in order to allow the neediest to have effective access to credits, then centralize the management of crops and sales of such brands that the redistribution of agro-sylvo-pastoral rents facilitates the recovery of debts and bring a profit proportional to the exploitation of any debtor, rural producer. Thus, a communal mediation that would act as a researcher and negotiator of the market to help farmers to market their products at a fair price via circuits adapted to national or international scale and have a considerable rent, will contribute to increase their possibility of return on investment 
and repayment of their agricultural credit in this period of COVID-19, whether their credit is in individual or group loan.

\section{References}

[1] Tchouassi, G. Tekam Oumbe, H. (2003). Microfinance and poverty reduction, the case of credit from the Sahel to Cameroon. International Review of the Social Economy. 288, 80-88.

[2] Servetus J.M. (2006). Barefoot bankers: microfinance. Paris: Editions Odile Jacob

[3] Doligez, F. \& Wampfler, B. (2007). Microfinance public policies and agricultural financing, issues and debates. Synthesis prepared for the symposium "What microfinance for agriculture in developing countries?", FARM, 4-6.

[4] Inter-réseaux \& El Ahmar, M.B. (2016). A return of banks in the financing of agriculture. Grain of Salt, 72, 15-17. 9-11.

[5] Twengembo (April-June 2004). Simplified recovery procedures. OHADATA D-06-28, juris periodical.

[6] Ministry of Small and Medium Enterprises of Social Economy and Handicrafts (2020). Consultation for the assessment of the needs of social economy units and the identification of priority value chains for the creation of decent jobs in Cameroon. Yaoundé-Cameroon: International Labour Organization.

[7] Kuikeu, O. V. (2020). "The Economic Impact of COVID-19 in Cameroon: An Approach through VAR Modelling". Munich Personal RePEc Archive, 99727, https://mpra.ub.uni-muechen.de/99727/.

[8] Okah Efogo, F., \& Okah Atenga, M.-F. (2020). Cameroon's COVID-19-proof exchanges in Africa. In. S. M. Mbenda \& V. Ondoua Biwole, Epidemiology of the economy and confinement of the COVID-19 organization (Dir., Chap. 8, Pp.127-142). Yaoundé: University Press of Yaoundé.

[9] Okouda, B. (2020). Impact of COVID-19 on the Cameroonian economy: Confinement or protectionism, beyond the emergency, an opportunity to achieve the rupture of our economic model. Yaoundé: Centre for Analysis and Research on Economic and Social Policies of Cameroon.

[10] Andrianarison, F. \& Nguem, B. E. (2020). Potential Socioeconomic Effects of COVID-19 in Cameroon: A Brief Assessment. Yaoundé, Cameroon: UNDP.

[11] Saba, A.A. (2012). Study on debt collection in the European common market. ERSUMA. Business Law - Professional Practice Review. $1,289-310$.

[12] Westley Glenn, D. (2006). Strategies and Structures for Commercial Banks in Microfinance. Department Best Practice Series, Washington, D.C: Inter-American Development Bank.

[13] Soglohoun, N. (2014). Financing agriculture by banks and microfinance institutions in Africa. Method of forecasting evaluation of agricultural activities, technique of analysis and financing of agricultural credit files: Analysis grid and decision ratios. https://www.microfinancegateway.org/sites/default/files/publication_files/financement_agricole_methodologie_outil_danalyse.pdf.

[14] Diouf, N. (n.a.). Debt collection and enforcement procedures. http://www.ohada.com/présentation-droitohada/catégorie/8/recouvrement-des-créances-et-les-voies-d-exécution.html.

[15] Economic and Monetary Community of Central African States (2002). Regulation No. 01/02/CEMAC/UMAC/COBAC, on the Conditions for the Exercise and Control of Microfinance Activity in the Economic and Monetary Community of Central Africa. N'Djamena: CEMAC.

[16] Takafo-Kenfack, D. (July 2018). Warning of creditors making new contributions to the debtor with a view to the continuation of the operation. Review of Business Law in Africa, No2, Edited by The Institute of French Right of Expression and Inscriptions.

[17] Lekane, T. D. (January-March 2003). Mutual Community Growth (MC2) and Rural Development in Baham (Cameroon). Les Cahiers d'Outre-mer, 221, 67-86.

[18] Djoum, K. S. (2008). Community Growth Mutuals (mc2), Cameroon: Decentralized community banks for the provision of services in remote areas. In Reaching Those Who Are Hard to Touch: A Comparative Study of Member-Owned Financial Institutions in Remote Rural Areas (pp. 1-32). Antigonish, Nova Scotia: COADY, International Institute, St. Franxis Xavier University.

[19] Laouan, F. Z. (2020). Rapid regional gender analysis in West Africa COVID-19. Bamako, Mali: CARE.

[20] Delavallade, c. (2014). Poverty and corruption: A vicious circle. Crossed views on the economy, 14, 72-83.

[21] Fouquet, B. (2010). Study on the financing of agriculture and the rural world: main report Mali. Food and Agriculture Organization of the United Nations, Foundation for Agriculture and Rurality in the World, Agricultural credit. http://www.fondationfarm.org/IMG/pdf/microfi20100701_rapport_principal.pdf.

[22] Civil Society Budget Advocacy Group (2014). Effectiveness of the Agriculture Credit Facility: Why poor farmers cannot access credit in Uganda! Uganda Civil Society Advocacy Group

[23] Samb, M. (2012). Study on the difficulties of debt collection in the WAEMU area: Case of Benin, Burkina Faso, Mali and Senegal". ERSUMA Review: Business Law - Professional Practice, 1, 279-288.

[24] Tamo Fogué, Y., Kamguang Boyom, H., Diémou Moumeyi, H. H., Kuété Kamta, A., \& Olina Bassala, J.-P. (2021). Participatory communal policies and agro-sylvo-pastoral entrepreneurship: The women's merchant garden in covid/post-covidic periods in 
West Cameroon. In Research paper from the Observatory of the economic Francophonie (DROFE, no. 15). University of Montreal: OFE. http://ofe.umontreal.ca.

[25] Niang, M., Cheikh Oumar, B.-A., Hathie, I., Tounkara, S., Sene, S. O., \& Ly, A. (2020). Effects of COVID-19 on agricultural and rural households in Senegal. Dakar: Agricultural and Rural Prospective Initiative. www.ipar.sn.

[26] Godquin, M. (2004). Microfinance Repayment Performence in Bangladesh: How to Improve the Allocation of Loans by MFls. World Development, 32 (11), 1909-1926.

[27] Honlonkou, A. N., Acclassato, D. H., \& Quenum, C. V.C. (2006). Determinants of Repayment Performance in Microfinance Institutions in Benin. Annals of public and cooperative Economics, 77(1), 53-81.

[28] Khandker, S. R., Barnes, D. F., \& Samad, H. A. (2013). Welfare Impacts of Rural Electrification: A Panel Data Analysis from Vietnam. Economic Development and Cultural Change, 61(3), 659-692.

[29] Samb, M. (2012). Study on the difficulties of debt collection in the WAEMU area: Case of Benin, Burkina Faso, Mali and Senegal". ERSUMA Review: Business Law - Professional Practice, 1, 279-288.

[30] Labie M. (1999). Microfinance in question: Organizational limits and choices. Brussels: Editions LUC PIRE.

[31] Laouan, F. Z. (2020). Rapid regional gender analysis in West Africa COVID-19. Bamako, Mali: CARE.

[32] Zeller, M. (1997). The Determinants of Credit Rationing: A Study of Informal Loanors and Formal Credit Groups in Madagascar. Economy Madagascar, 2, 175-198.

[33] Guerin. I et al. (2009). Microfinance, indebtedness and over-indebtedness: a case study in South India. Third World Review, $\mathrm{n}^{\circ} 197$.

[34] Kodio. A, (2010). Study on the financing of agriculture and the rural world in Mali. Supplementary Report-Analysis of supply and demand for agricultural financing. FARM, FAO, Agricultural credit.

[35] Paxton, J., Graham, D., \& Thraen, C. (2000). Modelling group loan Repayment: New Insights from Burkina Faso. Economic development and cultural change, 48(3), 639-655.

[36] Yonta, B. 2016. From market gardening to food-merchant: relevance of the choice of farmers in Galim (West Cameroon) in the face of agricultural risks. In J. G. Elong, For a rural geography of action (Pp. 133-145). Yaoundé: Editions CLE. 